\title{
THE EFFECT OF FISCAL BALANCE TRANSFER, FINANCIAL PERFORMANCE ON CAPITAL EXPENDITURE IMPACTING ON THE HUMAN DEVELOPMENT INDEX OF PAPUA PROVINCE
}

\author{
Bonifasia Elita Bharanti \\ elitabharanti@gmail.com
}

\begin{abstract}
The structure of Regional Development Budget (hereafter APBD) of Papua Province, which is mostly sourced from Government transfers tends to increase every year. This requires prioritising the use of capital expenditure that can improve the welfare of the community. However, it is an irony that the poverty rate in Papua Province ranks first in Indonesia as indicated by the Human Development Index $(H D I)$, below the national average $H D I$. The objective to analyse the structure of the APBD (General Allocation Fund - hereafter DAU, Special Allocation Fund - hereafter DAK and Revenue Sharing Fund - hereafter DBH) and financial performance of Papua's Human Development Index in 2013-2018 with capital expenditure as an intervening variable. Quantitative approach is used with secondary data type, which is processed using the IBM SPSS Amos application. This study indicate that the increasing APBD structure will be able to increase the HDI but capital expenditure does not mediate the APBD structure to the HDI. Furthermore, financial performance has no impact on increasing the $\mathrm{HDI}$ as the capital expenditure does not mediate financial performance on the human development index.
\end{abstract}

Keywords: Fiscal balance transfer, financial performance, capital expenditures, human development index

\section{PENDAHULUAN}

Dasar aturan mengenai Pemerintah Daerah adalah UU Nomor 523 Tahun 2014 yang telah mengalami berbagai revisi dari UU sebelumnya dan perubahan terakhir dengan UU Nomor 2 Tahun 2015 dan Undang-undang tahun 1999 Nomor 25 di ubah dengan Undang-undang No 33 Tahun 2004 mengenai Perimbangan Keuangan antara Pusat dan Daerah dimana kedua regulasi tersebut memberikan kewenangan luas kepada daerah untuk mengatur semua potensi keuangan yang dimiliki dengan sedikit campur tangan dari pemerintah pusat, seperti dalam proses perencanaan pembangunan dan penganggaran. Adanya kewenangan fiscal kepada daerah mengindikasikan bahwa pemerintah daerah harus dapat mengoptimalkan potensi daerahnya untuk memberikan kesejahteraan bagi masyarakatnya yang dicerminkan dengan anggaran belanja modal.

Pemerintah daerah menggunakan belanja modal diantaranya untuk pembangunan dan perbaikan disetor pendidikan, transportasi dan kesehatan, agar masyarakat dapat merasakan manfaat pembangunan daerah. Selanjutnya belanja modal tersebut digunakan 
untuk meningkatkan perekonomian serta pembangunan di daerah. Pada gilirannya strategi alokasi pembangunan ini diharapkan mampu mendorong dan mempercepat pembangunan ekonomi nasional juga dapat menjadi alat dalam pengurangan disparitas regional (Aziz \& Wulandari, 2014).

Peraturan Pemerintah No 19 tahun 2019 tentang Pengelolaan Keuangan Daerah menunjukkan . Komponen Pendapatan terdiri dari PAD, dana dari pusat, dan pendapatan lainnya yang sah. Belanja daerah diklasifikasikan menurut organisasi, fungsi, program dan kegiatan, serta jenis belanjanya. Berdasarkan table 1.1 dapat dilihat mengenai realisasi penerimaan dana perimbangan Propinsi Papua tahun 2014-2018.

\section{Tabel 1.1 Realisasi Penerimaan Dana Perimbangan Propinsi Papua 2014-2018}

(000)

\begin{tabular}{|c|c|c|c|c|c|}
\hline Tahun & DAU & DAK & DBH & $\begin{array}{c}\text { TOTAL DANA } \\
\text { PERIMBANGAN }\end{array}$ & APBD \\
\hline 2014 & 1.991 .202 .341 & 120.505 .640 & 493.139 .550 & 2.604847 .531 & 10.489 .108 .379 \\
\hline 2015 & $2.227,932.698$ & 165.303 .520 & 640006840 & 3.0832 .43 .058 & 11.357 .406 .827 \\
\hline 2016 & 2.502 .449 .117 & $503.446,688$ & 1.299 .465 .912 & 4.305 .361 .737 & 12.438 .141 .557 \\
\hline 2017 & 2.570 .118 .273 & $1.242,997,670$. & $606.163,244$ & $4 . .419 .279 .187$ & 13.968 .876 .704 \\
\hline 2018 & 2.570 .118 .273 & $1,222,125,989$ & 761.257300 & $4 . .553 .501 .562$ & 13.548 .512 .204 \\
\hline
\end{tabular}

Sumber: Data sekunder DJKP 2014-2018

Table 1.1 menunjukkan hampir $40 \%$ sumber pendapatan daerah Papua Dana perimbangan (DAU, DAK, DBH) yang cenderung setiap tahun mengalami peningkatan. Melihat hal ini sudah seharusnya Propinsi Papua dapat menggunakan sumber pendapatan ini untuk meningkatkan kesejahteraan masyarakatnya. Tetapi ironisnya penerimaan yang meningkat tidak diimbangi dengan meningkatnya tingkat kemiskinan dimana Propinsi Papua menempati urutan pertama di Indonesia. Ini ditunjukkan angka IPM dibawah rata-rata IPM Nasional. 


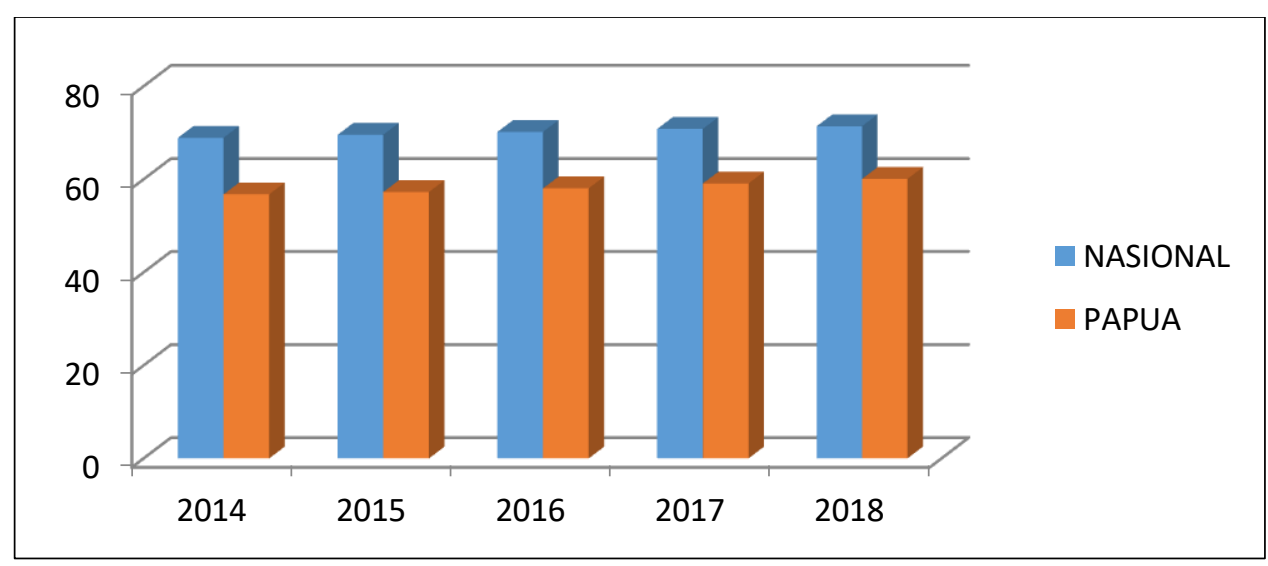

Grafik 1. IPM Propinsi Papua dan IPM Nasional 2014-2018

Sumber: BPS, Propinsi Papua, 2018

Kondisi riil yang terjadi terdapat 18 kabupaten yang rata-rata IPM nya berada di bawah rata-rata IPM Provinsi Papua pada tahun 2017 yaitu 59,09 \% Kabupaten Jayawijaya, Paniai , Puncak Jaya, Mappi, Asmat, Yahukimo, Pegunungan Bintang, Tolikara, Mamberamo Raya, Nduga, Lany Jaya, Mamberamo Tengah, Yalimo, Puncak, Dogiayi, Intan Jaya, Puncak, Yalimo. Selanjutnya kondisi riil pada tahun 2017 masih terdapat beberapa kabupaten/kota di Papua yang pertumbuhan ekonominya di bawah angka pertumbuhan ekonomi Provinsi Papua dan terdapat pertumbuhan ekonomi yang tumbuh negative. Hal ini membutuhkan perhatian dalam pengelolaan keuangan oleh Pemerintah daerah terutama untuk membiayai sektor sektor yang dapat mendongkrak pembangunan di daerah yang berdampak dapat meningkatkan kesejahteraan masyakat. Menurut Arsyad (1999) pembangunan ekonomi daerah, adalah suatu proses mengelola sumber daya lokal untuk merangsang tumbuhnya kegiatan ekonomi dan lapangan pekerjaan. Model pertumbuhan endogen mencerminkan proses pengelolaan potensi lokal yang menuntut peran aktif kebijakan publik untuk meningkatkan pembangunan ekonomi melalui investasi langsung maupun tidak langsung terhadap modal manusia (Human Capital). Dalam menerapkan kebijakan publik pemerintah daerah bisa menggunakan instrumen kebijakan fiskal seperti pendapatan daerah sebagai sumber pendanaan untuk belanja modal ke sektor-sektor yang dapat meningkatkan IPM. 
Faktor-faktor yang dapat mempengaruhi belanja modal menurut kajian empiris terdahulu diantaranya Novira sakira, dkk menemukan DBH dan DAU terbukti memiliki pengaruh terhadap belanja modal. Susanti \& Fahlevi (2016) menyatakan bahwa PAD, DAU dan DBH dapat mempengaruhi belanja modal. Farel (2015) menemukan bahwa PDRB, PAD, SiLPA berdampak positif terhadap belanja modal. Hal yang sama juga dikemukakan Sholikhah \& Wahyudin (2014) bahwa PAD, DBH dan luas wilayah berdampak pada meningkatnya belanja modal. Penelitian Sularso \& Restianto (2012) dan Praza (2016) membuktikan secara empiris bahwa semakin tinggi tingkat ketergantungan daerah maka akan dapat meningkatkan alokasi belanja modal.

Kusnandar \& Siswantoro (2012) mengatakan bahwa meningkatnya pengeluaran modal akan dapat meningkatkan pelayanan publik. Penelitian mengenai hubungan antara belanja modal dan IPM dikemukakan Sari \& Supadmi (2016) yang menemukan PAD dan belanja modal akan dapat meningkatkan IPM. Mirza (2012) dalam penelitiannya menyimpulkan kemiskinan memberikan dampak negatif pada IPM, namun dengan bertumbuhnya ekonomi dan belanja modal berdampak terhadap IPM.

Tingkat ketergantungan fiiskal suatu daerah dapat dilihat dari capaian kinerja keuangan Sularso \& Restianto (2012). Beberapa penelitian terdahulu mengenai kaitan antara kinerja keuangan dan IPM telah banyak dilakukan. Suryaningsih, Utama, \& Yasa (2015) meneliti kinerja keuangan daerah, dan upaya pemungutan PAD sebagai indikator kinerja keuangan daerah. Anggraini (2015) meneliti Pengaruh Kinerja Keuangan terhadap IPM di Indonesia. Hasil penelitiannya menunjukkan bahwa derajat desentralisasi serta kemandirian daerah berpengaruh terhadap IPM. Penelitian oleh Batafor (2011) mengenai Evaluasi kinerja Keuangan (tingkat ketergantungan dan kemandirian) dan Tingkat Kesejahteraan di Kabupaten Lembata menunjukkan meningkatnya kinerja keuangan akan dapat meningkatkan IPM sebagai indikator dari tingkat kesejahteraan.

Penelitian ini bertujuan menguji pengaruh dari dana perimbangan (DAU, DBH dan DAK) dan kinerja keuangan (tingkat ketergantungan dan derajat desentralisasi) terhadap IPM maupun secara tidak langsung melalui belanja modal. Kontribusi penelitian ini 
diharapkan dapat memberikan informasi untuk menentukan strategi yang tepat bagi daerah dalam pengalokasian belanja modal yang tepat sasaran dalam upaya peningkatan kesejahteraan yang dicerminkan dengan IPM.

\section{LANDASAN TEORITIS DAN PENGEMBANGAN HIPOTESIS}

\section{LANDASAN TEORI}

\section{Dana Perimbangan}

Peraturan yang mendasari pengelolaan keuangan daerah adalah PP Nomor 58 Tahun 2005 menjelaskan APBD terdiri dari pendapatan, Belanja daerah dan pembiayaan Pendapatan bersumber dari dua pendapatan asli daerah dan yang berasal dari Pemernitah Pusat selanjutnya disebut dana perimbangan yang terdiri dari :

\section{Dana Bagi Hasil (DBH)}

Berdasarkan Undang Undang No 23 Thn 2004 Dana Bagi Hasil merupakan alokasi dana transfer ke daerah yang berasal dari cukai, pajak dan sumber daya alam dengan pembagian berdasarkan prosentase tertentu yang ditujukan untuk mengurangi disparitas keuangan antara pusat dan daerah.. Pemerintah menetapkan alokasi DBH berdasarkan perhitungan tertentu daerah penghasil yang kemudian diberikan ke daerah sebagai penerimaan dalam tahun anggaran tersebut

\section{Dana Alokasi Umum (DAU)}

Berdasarkan Undang-Undang No 23 Tahun 2014, DAU diberikan untuk membiayai daerah dalam melaksanakan desentralisasi. Alokasi DAU tergantung pada kebutuhan fiskal di daerah Kuncoro (2004) mengemukakan DAU diberikan ke daerah untuk mengatasi kesenjangan antara kapasitas dan kebutuhan fiskal, yang dialokasikan berdasarkan aturan bahwa daerah miskin dan terbelakang menerima lebih besar dibandingkan daerah kaya. Tujuannya menurut Mardiasmo (2004) adalah untuk asas pemerataan dan keseimbangan fiskal, dimana dalam pembagiannya memperhatikan potensi daerah, kebutuhan pembiayaan, APBN. Ketentuannya DAU yang sedikit diberikan ke daerah kebutuhannya kecil tetapi 
potensi fiskal besar dan sebaliknya memperoleh DAU yang kecil, sebaliknya yg kebutuhannya besar dan potensi fiskal kecil DAU yang diterima relative besar.

Peraturan Pemerintah No 55 tahun 2005 dijelaskan bahwa (1) DAU diberikan untuk Propinsi dan kabupaten/kota (2) jumlah ditetapkan minimal $26 \%$ dari pendapatan bersih dalam negeri (3) Proporsi DAU dihitung dengan membandingkan besarnya urusan pemerimtah yg merupakan kewenangan daerah Mekanisme formulasi DAU.

Rumus:

$$
\mathbf{D A U}=\mathbf{A D}+\mathbf{C F}
$$

Keterangan:

DAU : Dana Alokasi Umum

AD : Alokasi Dasar yaitu Gaji PNS Daerah

CF : Celah Fiskal

\section{Dana Alokasi Khusus}

Dana Alokasi Khusus menurut UU No 23 Tahun 2014, adalah dana yang berikan untuk membiayai kegiatan tertentu yang merupakan prioritas nasional sesuai dengan fungsi yang telah ditetapkan dalam APBN, khususnya dalam upaya pemenuhan kebutuhan sarana dan prasarana pelayanan dasar masyarakat. Kegiatan khusus tersebut diutamakan untuk pengadaan/ peningkatan/ perbaikan sarpras fisik dan penunjang bagi pelayanan dasar masyarakat. Perhitungan Dana Alokasi Khusus melalui dua tahap 1) menentukan daerah tertentu berdasarkan kriteria; 2 ) menentukan besaran DAK. Kriteria umum mempertimbangkan kemampuan APBD daerah untuk membiayai pembangunan daerah Kriteria khusus didasarkan pada peraturan perundang undangan, terutama ketentuan yang mengatur kekhususan suatu daerah nerta karakteristik daerah yang meliputi daerah kepulauan dan pesisir, daerah yang berbatasan dengan negara lain, daerah tertinggal atau terpencil, daerah yang rawan bencana, serta daerah yang termasuk dalam daerah ketahanan pangan .Kriteria teknis ditetapkan oleh kementerian Negara atau departemen teknis terkait dengan indikator yang dapat mengambarkan kondisi sarana atau prasarana tiap kegiatan 
Penentuan besaran DAU untuk masing-masing daerah yang menerima Dana alokasi khusus didasarkan pada:

a. Daerah mempunyai indeks fiscal neto dibawah rata-rata IFN

b. Daerah yang sesuai dengan peraturan mengenai otonomi khusus

c. Daerah dengan indeks fiscal wilayah berada diatas rata-rata IFW nasional.

d. Daerah dengan indeks fiscal wilayah teknis berada diatas rata-rata IFWT nasional Penetapan besarnya Dana Alokasi Khusus masing-masing daerah ditentukan berdasarkan bobot Dana Alokasi Khusus per kegiatan /bidang dikalikan dengan penggunaan Dana Aokasi Khusus per bidang. Bobot Dana Alokasi Khusus per bidang ditetapkan berdasarkan indeks fiscal wilayah teknis (IFWT) dikalikan dengan indeks kelemahan konstruksi.

\section{Kinerja Keuangan Daerah (Fiskal)}

Ibnu (1986) dalam Susantih \& Saftiana (2009) mengemukakan kinerja keuangan merupakan kemampuan daerah menggali \& mengelola seluruh potensi Pendapatan Asli Daerah. Kinerja Pemerintah daerah dibidang pengelolaan keuangan dapat memberikan informasi yang penting untuk pengambilan kebijakan yang berdampak positif pada masyarakat. Pangkey, Saerang, \& Tulung (2017) Kinerja keuangan diukur dengan ratio desentralisasi fiscal, rasio tingkat ketergantungan, ratio efektifitas dan ratio expenditure capital

\section{Tingkat Ketergantungan Daerah}

Tingkat Ketergantungan Daerah menggambarkan tingkat ketergantungan suatu daerah terhadap bantuan external baik dari Pusat maupun Provinsi. Semakin besar nilainya semakin tidak mandirinya begitu juga sebaliknya. Rasio ketergantungan dihitung dengan membagi seluruh pendapatan transfer dengan total pendapatan daerah. Perhitungan Rasio ketergantungan sebagai berikut: 
Tingkat Ketergantungan $=\frac{\text { Jumlah pendapatan transfer }}{\text { Total pendapatan daerah }} \times 100 \%$

Tabel 3. Skala Interval Tingkat Ketergantungan

\begin{tabular}{|c|c|}
\hline Rasio Ketergantungan (\%) & Ketergantungan Pemerintah Daerah \\
\hline $0,00-10,00$ & Sangat rendah \\
\hline $10,01-20,00$ & Rendah \\
\hline $20,01-30,00$ & Sedang \\
\hline $30,01-40,00$ & Cukup \\
\hline $40,01-50,00$ & Tinggi \\
\hline$>50,00$ & Sangat Tinggi \\
\hline
\end{tabular}

Sumber: Tim LITBANG I FISIPOL UGM 1991) dalam (Bisma \& Susanto, 2010)

\section{Rasio Derajat Desentralisasi}

Desentralisasi adalah melaksanakan urusan yang menjadi kewengan pusat kepada daerah berdasarkan asas otonomi. Ukuran Keberhasilan desentralisasai suatu daerah dengan melihat sumbangan potensi pendapatan yang dihasilkan daerah (PAD) dengan total pendapatan daerah. Idealnya daerah harus dapat membiayai seluruh kebutuhannya dengan mengunakan pendapatan yang dihasilkan sendiri (PAD) Rasio ini dihitung berdasarkan rumus:

$$
\text { Derajat desentralisasi fiscal }=\frac{P A D}{\text { Total pendapatandaerah }} x 100 \%
$$

Tabel 4. Skala Interval Ratio Desentralisasi fiscal

\begin{tabular}{|c|c|}
\hline Rasio Desentralisasi Fiskal (\%) & Kemampuan Keuangan Pemerintah Daerah \\
\hline $0,00-10,00$ & Sangat Kurang \\
\hline $10,01-20,00$ & Kurang \\
\hline $20,01-30,00$ & Sedang \\
\hline $30,01-40,00$ & Cukup \\
\hline $40,01-50,00$ & Baik \\
\hline$>50,01$ & Sangat Baik \\
\hline
\end{tabular}

Sumber: Tim LITBANG FISIPOL UGM , 1991 dalam (Bisma \& Susanto, 2010)

\section{Belanja Modal}

Belanja modal yaitu pengeluaran yang manfaatnya dapat menambah asset pemerintah yang berdampak pada meningkatnya biaya pemeliharaan (Mardiasmo, 2004). 
Belanja modal umumnya dialokasikan untuk penyediaan sarpras berwujud aset tetap berupa bangunan, infrastruktur dan peralatan serta aset tetap lainnya, yang digunakanan untuk mendukung tugas-tugas pemerintah dan penyediaan fasuilitas publik (Darwanto \& Yulia, 2007). Belanja modal berperan penting meningkatkan infrastruktur publik yang dapat meningkatkan pertumbuhan ekonomi, Mardiasmo (2009) menggemukakan secara umum dengan semakin tinggi tingkat investasi modal diharapkan dapat memperbaiki kualitas pelayanan publik yang berimplikasi pada semakin meningkatnya partisipasi publik terhadap pembangunan. Kuncoro (2004), mengatakan pembangunan sarpras oleh pemda akan berdampak meningkatnya pertumbuhan ekonomi, dengan bertambahnya pelayanan sektor publik setiap tahun akan meningkatkan fasilitas kesehatan, pendidikan, dan fasilitas penunjang lainnya. Hal ini diharapkan dapat memacu pertumbuhan ekonomi di daerah (Harianto \& Adi, 2007). Budiartha, Badera, \& Tonu (2015) menemukan semakin tinggi alokasi belanja modal semakin tinggi daya saing daerah. Halim (2008) mengemukakan jenis-jenis belanja modal diperuntukkan untuk belanja: Mesin dan peralatan, tanah, gedung dan bangunan, irigas, jalan, dan jaringan, asset tetap, dan asset lainnya.

\section{Indeks Pembangunan Manusia (IPM)}

IPM adalah indikator yang mengukur keberhasilan kualitas hidup manusia (masyarakat/penduduk) di suatu deerah sebagai dampak dari adanya pembangunan. IPM diukur dengan mengunakan 3 indeks, yaitu (BPS, 2015):

\section{Indeks Harapan Hidup}

Indeks ini menggambarkan tingkat kualitas hidup masyarakat yang dilihat dari umur yang panjang dan sehat (longevity) . Dilihat dari dua ukuran Anak Lahir Hidup (ALH) dan Anak Masih Hidup (AMH). Besarnya nilai maksimum sebagai standar UNDP adalah 85 dan minimum 25 tahun

\section{Indeks Pendidikan}

Indeks ini perwujudan dimensi pengetahuan (knowledge). Perhitungannya menggunakan dua indikator, yaitu: Angka harapan Lama sekolah (Expected Years of Schooling) dan rata-rata lama sekolah (Man Years School) yang telah dijalani anak 
usia 15 tahun keatas Diharapkan Dengan semakin baiknya tingkat Pendidikan dan kesehatan dapat memberikan peluang mendapatkan penghasilan yang lebih tinggi (Lanjouw, Pradhan, Saadah, Sayed, \& Sparrow, 2001), yang nantinya berdampak pada meningkatnya kesejahteraan dan kualitas manusianya.

\section{Indeks Standar Kelayakan Hidup}

Indeks ini mencerminkan kelayakan hidup (decent living). BPS menggunakan nilai rata rata pengeluaran perkapita dan daya beli (Purchasing Power Parity-PPP). Dimana tahun dasar yang digunakan tahun $2012=100$ untuk menghitung pengeluaran per kapita rata rata sedangkan Daya beli dihitung 66 komoditas merupakan makanan dan sisanya komoditas non makanan.

Pengukuran IPM telah mengalami beberapa perubahan sejak pertama kali dicetuskan dan yang terpenting adalah indeks tersebut telah disederhanakan sehingga sekarang IPM dihitung secara langsung. Pertumbuhan dalam modal fisik bisa saja melimpah ke modal manusia melalui investasi swasta dalam riset dan pengembangan serta pelatihan dalam teknologi yang lebih tinggi yakni dalam pertumbuhan yang didorong oleh teknologi. Untuk dapat melestarikan pertumbuhan angkatan kerja sebagian besar (dan semakin meningkat besarnya) harus memiliki latar belakang sekolah umum yang cukup supaya dapat menguasai keterampilan teknologi serta berpartisipasi dalam perluasan aktivitas riset dan Oleh karena itu, sekolah umum yang disediakan secara publik dan pengetahuan yang dihasilkan secara privat bersifat komplementer.

\begin{tabular}{|c|c|}
\hline Interval IPM & Kategori \\
\hline $0-50$ & Rendah \\
\hline $51-79$ & Moderat/Sedang \\
\hline $80-100$ & Tinggii \\
\hline
\end{tabular}

Sumber: Kuncoro, 2015 


\section{PENGEMBANGAN HIPOTESIS}

\section{Pengaruh Dana Perimbangan Terhadap Indeks Pembangunan Manusia}

PP Nomor 58 Tahun 2005 menjelaskan APBD terdiri dari komponen pendapatan asli daerah, dana transfer, dan pendapatan lainnya yang sah. APBD mencerminkan kebijakan dalam satu tahun anngaran terkait penentuan prioritas program dan kegiatan yang merupakan perwujudan peran dan tanggung jawab pemda dalam mengelola pembangunan untuk mencapai kemakmuran masyarakat. Swandewi (2014) mengemukakan bahwa sudah semestinya meningkatnya penerimaan daerah yang dicerminkan dengan peningkatan sumber-sumber penerimaan dapat meningkatkan pendapatan rumah tangga sehingga kesejahteraan meningkat yang dapat dilihat dari IPM. Dari penjelasan diatas dikemukakan hipotesis:

\section{H1: Diduga semakin meningkatnya Dana perimbangan dapat meningkatkan Indeks} Pembangunan Manusia.

Pengaruh Dana Perimbangan Terhadap Indeks Pembangunan Manusia Yang

\section{Dimediasi Oleh Belanja Modal}

Sumber Pendapatan Daerah yang diterima yang salah satunya berasal dari Dana perimbangan digunakan untuk membantu pembiayaan kebutuhan tertentu yang merupakan juga program nasional maupun untuk mempercepat pembangunan dan mengurangi disparitas kesenjangan antar daerah. Dengan pendapatan tersebut dialokasikan melalui belanja pemerintah daerah salah satunya meningkatkan Belanja modal merupakan output APBD yang paling dapat mempengaruhi pembangunan khususnya IPM yang merupakan indikator kesejahteraan masyarakat dan pertumbuhan ekonomi daerah. Sartika, Kirmizi, \& Indrawati (2017) menemukan bahwa komponen struktur APBD (DBH, DAU) secara parsial berpengaruh terhadap Belanja Modal, sedangkan Christy \& Adi (2009) menemukan bahwa DAU berdampak positif terhadap belanja modal. Kusnandar \& Siswantoro (2012), dengan meningkatnya pengeluaran modal diharapkan pelayanan publik meningkat sehingga berimbas pada peningkatan IPM. Penelitian mengenai belanja modal dan IPM pernah dilakukan oleh Sari \& Supadmi (2016) dan Mirza (2012) yang menemukan belanja modal 
berdampak pada meningkatnya IPM. Berdasarkan kajian penelitian terdahulu dikembangkan hipotesis :

H2: Diduga Meningkatnya Dana Perimbangan Akan Dapat Meningkat Biaya Modal Yang Berdampak Pada Peningkatan Indeks Pembangunan Manusia

\section{Pengaruh kinerja keuangan terhadap Indeks Pembangunan Manusia}

Anggraini (2015) Hasil penelitiannya menunjukkan bahwa derajat desentralisasi dan kemandirian daerah berpengaruh terhadap IPM. Batafor (2011) Hasil penelitian adalah dengan semakin baiknya kinerja keuangan daerah menyebabkan terjadinya peningkatan IPM. Batafor (2011) Peningkatan tingkat kemandirian, efektivitas, efisiensi, dan keserasian belanja menyebabkan kesejahteraan masyarakat meningkat yang dapat dilihat dari IPM. Amalia \& Purbadharmaja (2014) menemukan Tingkat Kemandirian keuangan secara berpengaruh terhadap IPM. Suryaningsih, Utama, \& Yasa (2015). Suryaningsih et al. (2015) menemukan Kinerja keuangan daerah dapat meningkatkan IPM. Berdasarkan kajian penelitian terdahulu dapat dikemukakan hipotesis sebagai berikut:

H3: Diduga Dengan Kinerja Keuangan Yang Semakin Baik Yang Dilihat Dari Rasio Ketergantungan Keuangan Dan Rasio Derajat Desentralisasi Dapat Meningkatkan IPM

\section{Pengaruh belanja modal terhadap Indeks Pembangunan Manusia}

Penelitian Sularso \& Restianto (2012) membuktikan secara empiris bahwa tingkat ketergantungan daerah memberikan dampak positif pada belanja modal. Penelitian Praza (2016) yang menyatakan bahwa derajat desentralisasi berpengaruh positif terhadap alokasi belanja modal. Yanto, Ridwan, \& Fattah (2018) menemukan indeks pembangunan manusia dapat ditingkatkan melalui belanja modal yang tepat. Menurut Martini \& Dwirandra (2015) bahwa kinerja keuangan berdampak pada peningkatan belanja modal. Sari \& Supadmi (2016) dan Mirza (2012) menemukan belanja modal dapat meningkatkan secara signifikan IPM. Berdasarkan kajian penelitian terdahulu maka dikembangkan hipotesis sebagai berikut:

H4: Diduga Semakin Baik Kinerja Keuangan Akan Meningkatkan Belanja Modal Yang 


\section{Berdampak Pada Meningkatnya Indeks Pembangunan Manusia}

\section{METODE PENELITIAN}

\section{Desain Penelitian}

Penelitian menggunakan desain kuantitatif dengan jenis penelitian asosiatif yaitu penelitian yang bertujuan menjelaskan hubungan dan pengaruh antara variabel dan menguji hipotesis yang dikembangkan,

\section{Populasi dan sampel}

Populasi dan sampel penelitian adalah seluruh kabupaten/kota di Propinsi Papua sebanyak 29 kabupaten/ Kota .

Teknik Pengumpulan Data

Pengumpulan data dengan metode dokumentasi yang bersumber dari laporan DJKP dan BPS tahun 2013-2018

\section{Teknik Analisis Data}

Teknik analisis data yang digunakan adalah Moderated Regression Analysis (MRA) dengan bantuan aplikasi AMOS versi 21, Tahap analisis sebagai berikut : pengujian asumsi klasik, dan pengujian hipotesis digunakan analisis jalur dan uji sobel test

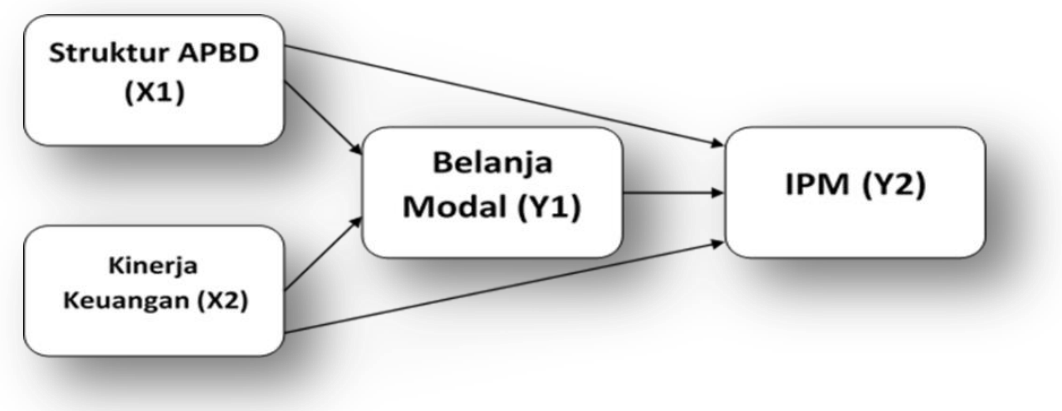

Gambar 1: Model penelitian

HASIL PENELITIAN DAN PEMBAHASAN

HASIL PENELITIAN

Pengujian Asumsi Klasik

\section{Uji Normalitas}


Uji Normalitas menggunakan Kolmogorov-Smirnov dengan hasil perhitungannya pada table 6 berikut:

Tabel 6. Hasil Uji KS-1 Sample

\begin{tabular}{|c|c|c|}
\hline \multicolumn{3}{|c|}{ One-Sample Kolmogorov-Smimov Test } \\
\hline & & $\begin{array}{c}\text { Unstandardized } \\
\text { Residual }\end{array}$ \\
\hline \multicolumn{2}{|l|}{$\mathbf{N}$} & 174 \\
\hline \multirow{2}{*}{ Normal Parameters ${ }^{a, b}$} & Mean & 0,0000000 \\
\hline & $\begin{array}{l}\text { Std. } \\
\text { Deviation }\end{array}$ & 0,30388407 \\
\hline \multirow[t]{3}{*}{ Most Extreme Differences } & Absolute & 0,065 \\
\hline & Positive & 0,039 \\
\hline & Negative & $-0,065$ \\
\hline \multicolumn{2}{|l|}{ Test Statistic } & 0,065 \\
\hline \multicolumn{2}{|c|}{ Asymp. Sig. (2-tailed) } &, $074^{\circ}$ \\
\hline \multicolumn{3}{|l|}{ a. Test distribution is Normal. } \\
\hline \multicolumn{3}{|c|}{ b. Calculated from data. } \\
\hline \multicolumn{3}{|c|}{ c. Lilliefors Significance Correction. } \\
\hline
\end{tabular}

Sumber: Data primer diolah, 2019)

Berdasarkan output SPSS di atas dengan menggunakan metode Kolmogorov Smirnov diketahui bahwa nilai IF Sig $0,074>0,05$ sehingga model berdistribusi normal .

\section{Uji Heteroskedastisitas}

Uji heteroskedastisitas menguji ketidaksamaan probabilitas ( varians) suatu residual dari seluruh pengamatan, bila tidak terpenuhi dinyatakan tidak bisa digunakan untuk peramalan.

\section{Grafik 2 Hasil Uji Heteroskedastisitas}

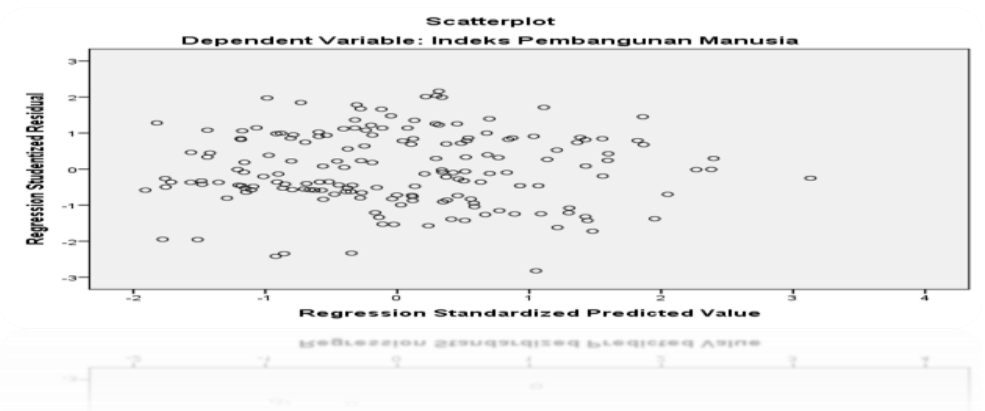

Sumber: Data primer diolah, 2019)

Pada Grafik 2 diagram pencar menunjukkan model regresi linear berganda tidak terdapat gejala atau masalah heteroskedastisitas. Gambar grafik diatas memperlihatkan data menyebar tidak beraturan membentuk pola yang tidak teratur. Maka disimpulkan tidak terjadi heteroskedastisitas

\section{Uji Multikolinieritas}


Uji Multikolinieritas digunakan untuk melihat ada tidaknya interkorelasi / hubungan antar variabel independen.

Tabel 7 Hasil Uji Multikolinieritas

\begin{tabular}{|c|c|c|c|c|c|c|}
\hline \multicolumn{7}{|c|}{ Coefficients $^{a}$} \\
\hline \multicolumn{2}{|r|}{ Model } & \multicolumn{2}{|c|}{ Unstandardized Coefficients } & \multirow{2}{*}{$\begin{array}{c}\begin{array}{c}\text { Standardized } \\
\text { Coefficients }\end{array} \\
\text { Beta }\end{array}$} & \multicolumn{2}{|c|}{ Collinearity Statistics } \\
\hline & & $\mathrm{B}$ & Std. Error & & Tolerance & VIF \\
\hline \multirow{4}{*}{1} & (Constant) & $-24,797$ & 86,624 & & & \\
\hline & $\begin{array}{l}\text { Dana } \\
\text { perimbangan }\end{array}$ & 18,271 & 4,118 & 0,416 & 0,559 & 1,788 \\
\hline & Kinerja Keuangan & $-13,174$ & 13,956 & $-0,067$ & 0,985 & 1,016 \\
\hline & Belanja Modal & $-15,523$ & 2,718 & $-0,538$ & 0,553 & 1,808 \\
\hline
\end{tabular}

Sumber: Data primer diolah, 2019

Dari tabel di atas terlihat bahwa semua variabel mempunyai nilai Tolerance $>010$ dan nilai $\mathrm{VIF}<10,0$. Sehingga dapat disimpulkan bahwa tidak terjadi Multikolinieritas

Tabel 8 Pengujian Goodness of Fit Model penelitian

\begin{tabular}{|c|c|c|c|}
\hline Goodness of fit & Cut of & Hasil perhitungan & keterangan \\
\hline P Value & $\geq 0.05$ & 0,417 & MODEL BAIK \\
\hline CMIN/DF & $\leq 2.00$ & 0,666 & MODEL BAIK \\
\hline GFI & $\geq 0,90$ & 0,998 & MODEL BAIK \\
\hline AGFI & $\geq 0,90$ & 0,981 & MODEL BAIK \\
\hline TLI & $\geq 0,95$ & 1,016 & MODEL BAIK \\
\hline CFI & $\geq 0.95$ & 1.00 & MODEL BAIK \\
\hline RMSEA & $\leq 0,08$ & 0.000 & MODEL BAIK \\
\hline
\end{tabular}

(Sumber: Data lampiran)

Berdasarkan tabel 8 dapat dilihat dari t kriteria yang digunakan memenuhi spesifikasi model yang baik sehingga model ini dapat untuk menjelaskan variable-variabel penelitian yang digunakan.

\section{Pengujian Hipotesis}

\section{Pengujian Pengaruh Langsung}

Pengujian pengaruh langsung dan pengaruh tidak langsung digunakan untuk menjawab hipotesis. Untuk mengetahui hasil uji hipotesis digunakan analisis jalur. (Path Analyzed). Berdasarkan hasil statistik tabel 9 dan gambar 3, dapat dijelaskan analisis jalur sebagai berikut: 
1. Pengujian pengaruh langsung antara Dana perimbangan terhadap belanja modal diperoleh koefisien jalur sebesar 0,661 dan $P$ value 0,000 . Karena nilai $P$ value kurang dari 0,05 mengindikasikan bahwa adanya pengaruh yang signifikan dan positif .

2. Pengujian pengaruh langsung kinerja keuangan terhadap belanja modal diperoleh koefisien jalur sebesar $-0,081$ dan $P$ Value 0,168 . Karena nilai $P$ value lebih dari 0,05 mengindikasikan bahwa ada pengaruh negative tetapi tidak signifikan.

3. Pengujian pengaruh langsung antara Dana perimbangan terhadap IPM diperoleh koefisien jalur sebesar 0,416 dan $P$ Value 0,000 . Karena nilai $P$ value kurang dari 0,05 mengindikasikan bahwa ada pengaruh positif dan signifikan (H1 Diterima).

4. Pengujian pengaruh langsung kinerja keuangan terhadap IPM diperoleh koefisien jalur sebesar $-0,046$ dan $P$ Value 0,168 . Karena nilai $P$ value 0,347 lebih dari $\quad 0,05$ mengindikasikan bahwa tidak ada pengaruh signifikan (H3 Ditolak).

5. Pengujian pengaruh langsung belanja modal terhadap IPM diperoleh koefisien jalur sebesar $-0,536$ dan $P$ Value 0,000 . Karena nilai $P$ value kurang dari 0,05 mengindikasikan bahwa ada pengaruh negative dan signifikan.

\section{Pengujian pengaruh tidak langsung (Uji Sobel test)}

Berdasarkan hasil pengujian dengan dapat dilihat bahwa:

1. Pengujian efek mediasi belanja modal pada pengaruh struktur APBD terhadap IPM diperoleh koefisien jalur tidak langsung sebesar 0,354 dan $Z$ hit $=0,198$ pada $P$ Value sebesar 0,842. Karena Zhit $=0,198$ lebih kecil dari $Z$ table $=1,96$ dan nilai $p$ value $0,842 \geq 0,05$ mengindikasikan belanja modal tidak dapat memediasi pengaruh dari struktur APBD terhadap IPM (H2 Ditolak).

2. Pengujian efek mediasi belanja modal pada pengaruh Kinerja keuangan terhadap IPM diperoleh koefisien jalur tidak langsung sebesar 0,429 dan $Z$ hit = 0,195 pada $p$ value sebesar 0,845 Karena Zhit $=0,195$ lebih kecil dari $Z$ table $=1,96$ dan nilai 
$\mathrm{p}$ value $0,845 \leq 0,05$ mengindikasikan belanja modal tidak dapat memediasi pengaruh dari Kinerja keuangan terhadap IPM (H4 Ditolak).

Tabel 9 Ringkasan Hasil Pengujian Hipotesis

\begin{tabular}{|c|c|c|c|c|c|c|}
\hline $\begin{array}{c}\text { Variable } \\
\text { independent }\end{array}$ & $\begin{array}{c}\text { Variable } \\
\text { dependent }\end{array}$ & Variable mediasi & koef & Zhit & P value & keputusan \\
\hline \multicolumn{7}{|c|}{ Pengaruh Langsung (Direct Effect) } \\
\hline Struktur APBD & IPM & - & 0.416 & - & 0.000 & diterima \\
\hline Kinerja Keuangan & IPM & - & 0.064 & - & 0.347 & ditolak \\
\hline \multicolumn{7}{|c|}{ Pengaruh tidak Langsung (Indirect Effect) } \\
\hline Struktur APBD & IPM & Belanja modal & 0.354 & 0,198 & 0,842 & ditolak \\
\hline Kinerja Keuangan & IPM & Belanja modal & 0.429 & 0,195 & 0.845 & ditolak \\
\hline
\end{tabular}

Sumber: Data Diolah

\section{Gambar 3 : Hasil Uji Model Penelitian}

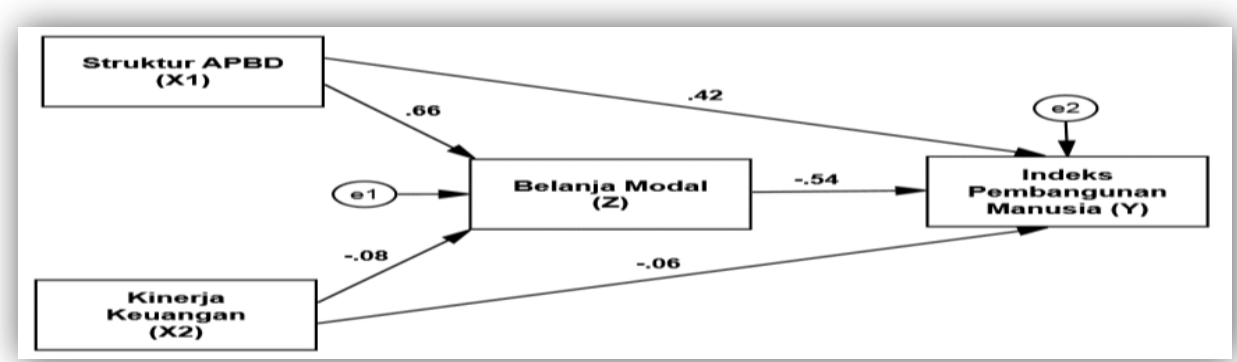

\section{PEMBAHASAN}

\section{Pengaruh Dana Perimbangan terhadap Indeks Pembangunan Manusia}

APBD adalah perwujudan kebijakan pemerintah daerah untuk menentukan prioritas program atau kegiatan yang menjadi tanggung jawab pemerintah daerah.dalam pengelolaan pembangunan. Dalam komponen struktur pendapatan Daerah terdapat komponen dana perimbangan (DBH. DAU, DAK) yang berasal dari pusat untuk membantu daerah dalam mengatasi disparitas antar daerah dan pembiayaan program pusat yang menjadi kewenangan di daerah. Diharapkan bahwa semakin meningkatnya pendapatan daerah akan dapat dipakai untuk membiayai berbagai macam program prioritas di bidang pendidikan, kesehatan, ekonomi yang akan menciptakan produktivitas, pemerataan, kesinambungan dan pemberdayaan dapat meningkatkan IPM.

Berdasarkan hasil pengujian hipotesis satu $(\mathrm{H} 1)$ diterima artinya terdapat pengaruh dari Dana perimbangan (DBH, DAU, DAK) terhadap IPM dengan $p$ value $0.000 \leq 0.05$ Ini 
menunjukkan dengan semakin besar penerimaan dana perimbangan dapat meningkatkan IPM. Hal ini dapat ditunjukkan berdasarkan data 2013-2018 terlihat meningkatnya rata-rata dana perimbangan sebesar $6,11 \%$ per tahun yang berdampak pada meningkatnya IPM sebesar $1,33 \%$ per tahun.

Anggaran daerah yang dialokasikan harus benar-benar mampu menjawab tuntutan masyarakat melalui berbagai program dan kegiatan yang dapat meningkatkan kualitas layanan public, seperti pendidikan, kesehatan, kebersihan, keamanan ketertiban, dan lain sebagainya dengan memperhatikan potensi keanekaragaman daerah . Hasil penelitian ini tidak sejalan dengan penelitian Anim (2018) yang menunjukkan dana perimbangan tidak memberikan dampak pada meningkatnya indeks pembangunan manusia. Penelitian yang dilakukan oleh rRiva (2017) juga menunjukkan bahwa dana perimbangan tidak berpengaruh terhadap indeks pembangunan manusia tetapi sejalan dengan penelitian Swandewi (2014) yang mengemukakan bahwa sudah semestinya meningkatnya penerimaan daerah yang dicerminkan dengan peningkatan sumber-sumber penerimaan termasuk di dalamnya adalah dana perimbangan akan diikuti oleh peningkatan kesejahteraan (pendapatan perkapita dan IPM) sebagai indikator pengukurannya.

Hasil penelitian ini juga menunjukkan Pemerintah Daerah di Propinsi Papua telah memanfaatkan kewenangannya yang diberikan oleh pemerintah pusat dengan mengalokasikan anggarannya dalam pembangunan di daerah dengan menerapkan prioritas program-program di berbagai bidang baik bersifat non ekonomis maupun ekonomis yang bersifat produktif sehingga memberikan dampak pada meningkatnya tingkat kesejahteraan masyarakat yang dicerminkan dengan meningkatkannya IPM.

\section{Pengaruh Dana Perimbangan terhadap Indeks Pembangunan Manusia yang di mediasi oleh Belanja Modal}

Berdasarkan hasil analisis jalur diperoleh hasil bahwa secara langsung Struktur APBD yang diwakili oleh dana perimbangan berdampak pada peningkatan belanja modal tetapi meningkatnya belanja modal justru berdampak negative pada IPM. Hal ini dapat dijelaskan bahwa Struktur APBD yang diwakili oleh Dana perimbangan (DAU DAK, DBH) 
secara umum adalah merupakan dana transfer dari pemerintah yang bersifat block grand maupun dialokasikan ke daerah-daerah dengan tujuan untuk mengurangi kesenjangan kemampuan daerah dalam membiayai pembangunan. Semakin meningkat pendapatan dari dana perimbangan(DBH, DAU, DAK) akan meningkatkan pengeluaran modal untuk membelanjakan investasi dalam aktiva tetap, baik berupa sarana dan prasarana di bidang pendidikan, kesehatan, infrastruktur, perekonomian dan kemudahan fasilitas yang dapat meningkatkan pelayanan public yang prima yang dalam jangka panjang akan meningkatkan kesejahteraan masyarakat.

Berdasarkan hasil uji pengaruh parsial dari Dana perimbangan terhadap Belanja modal sejalan dengan penelitian (Hendarmin, 2012; Sartika et al., 2017; Swandewi, 2014) yang menemukan ada pengaruh yang positif signifikan dari DAU, DAK, DBH terhadap belanja modal. Sedangkan pengaruh secara parsial dari belanja modal terhadap IPM memiliki pengaruh yang negative dan signifikan terhadap IPM, Ini menunjukkan bahwa Peningkatan belanja modal tidak menyebabkan meningkatnya IPM dikarenakan belanja modal terutama yang bersifat investasi tetap tidak berdampak dalam jangka pendek (Short term ) terlihat tetapi dalam jangka panjang (long term) akan berkontribusi pada peningkatan kesejahteraan masyarakat. Hal ini juga terlihat pengaruh yang negatif menunjukkan bahwa semakin meningkatnya belanja modal akan mengurangi IPM . Dapat dijelaskan berdasarkan data belanja modal di Papua rata-rata sekitar 27,76 \% dari APBD. Menurut Badrudin dalam Zebua (2014) alokasi belanja daerah dipandang belum efektif dalam pencapaian kesejahteraan masyarakat Angka ini jauh dari angka ideal yang seharus diatas $30 \%$ dari alokasi APBD. Baru akan berdampak pada pengikatan IPM. Jika alokasi belanja modal tepat seperti pembenahan infrastruktur, fasilitas umum yang memadai sehingga akan dapat meningkatkan kualitas dan kuantitas, serta meningkatkan produktivitas daerah, pendapatan masyakat dan IPM. Semakin rendahnya alokasi belanja modal untuk pembangunan daerah dan sebaliknya terjadi peningkatan proporsi alokasi belanja pegawai yang tidak berpengaruh langsung pada pembangunan daerah .padahal dan komposisi alokasi penggunaannya harus 
pada bidang-bidang prioritas seperti pendidikan, kesehatan, perekonomian yang dapat menciptakan produktivitas bagi masyarakat.

Dari Hasil uji mediasi diperoleh hasil bahwa nilai $p$ value $0,842>0,05$ sehingga hipotesis 2 ditolak berarti. Meningkatnya dana perimbangan tidak berdampak pada meningkatnya belanja modal yang berimbas pada meningkatnya IPM, Ini dapat dijelaskan bahwa belanja modal tidak seluruhnya di danai dari dana perimbangan (DAU, DAK, DBH) karena dana perimbangan hanya menyumbangi rata-rata sebesar $27,67 \%$ dari total APBD sisanya dari pendapatan lainnya. Kontribusi yang kecil ini juga berdampak pada kecilnya kontribusi ke belanja modal yang terkait dengan terbatasnya sarana dan prasarana publik yang tersedia di bidang ekonomi, kesehatan, pendidikan sehingga tidak berdampak dalam jangka pendek tetapi membutuhkan waktu yang lama untuk dapat memberikan dampak terhadap peningkatan IPM. Meningkatnya belanja modal tidak berarti berdampak pada peningkatan IPM manakala alokasinya tidak tepat digunakan untuk peningkatan kualitas layanan publik yang memberikan dampak pada kemakmuran masyarakatnya.

\section{Pengaruh Kinerja keuangan terhadap Indeks Pembangunan Manusia}

Kinerja keuangan adalah alat untuk menilai kinerja pemda yang dapat memberikan informasi yang penting untuk pengambilan kebijakan yang berdampak positif pada masyarakat (Pangkey et al., 2017), sejalan dengan itu Mahmudi (2010) mengemukan analisis ratio keuangan ada beberapa diantaranya adalah ratio desentralisasi fiscal dan rasio tingkat ketergantungan.

Berdasarkan hasil perhitungan statistic diperoleh bahwa kinerja keuangan berpengaruh negative tidak signifikan terhadap indik pembangunan manusia sehingga hipotesis 3 ditolak artinya secara langsung kinerja keuangan yang dicapai secara umu di seluruh Kabupaten/kota di propinsi Papua belum mampu mendongkrak Indeks Pembangunan Manusia di daerah masing masing. . Hal ini dapat dijelaskan bahwa kinerja keuangan yang diukur dari tingkat ketergantungan dan tingkat desentralisasi menunjukkan bahwa tingkat ketergantungan Propinsi Papua terhadap Pemerintah pusat sangat tinggi dengan rata-rata tingkat ketergantungan 90,66 \% dan tingkat desentralisasi fiscal cukup 
rendah dengan rata-rata $29,67 \%$. Hasil penelitian membuktikan bahwa tingkat ketergantungan yang tinggi dan derajat desentralisasi fiscal yang rendah tidak akan berdampak pada pelayanan publik yang baik dikarenakan pendapatan transfer yang ada digunakan untuk menutupi pos belanja tidak langsung yang tidak mampu dipenuhi hanya dengan PAD sehingga jika pelayanan public kurang baik maka tidak akan berdampak pada IPM. Ini menunjukkan bahwa potensi lokal di Papua belum digali secara maximal. Jika pemerintah daerah dapat meningkatkan dan mengembangkan potensi local akan dapat meningkatkan rasio desentralisasi fiscal dan tingkat ketergantungan terhadap pemerintah pusat akan berkurang, sehingga kemakmuran masyarakat semua kabupaten/kota di Papua diprediksi akan meningkat. Secara ringkas penelitian ini menyimpulakn bahwa dengan masih tingginya tingkat ketergantungan dan tingkat desentralisasi di sebagian besar kabupaten /kota di Papua menyebabkan daerah-daerah kurang dapat membuat program yang strategis sesuai dengan kebutuhannya pelayanan public di daerah sehingga tingkat kesejahteraan masyakat belum tercapai. Dapat terlihat dari IPM rata-rata Propinsi di Papua lebih rendah dibandingkan dengan daerah yang lain dan menempati urutan terakhir secara nasional. Dan secara umum masih banyaknya kabupaten yang berada dibawah IPM Propinsi karena mengalami pertumbuhan yang negatif .

Penelitian ini dapat dijelaskan oleh Anggraini (2015) menyatakan bahwa daerah yang memiliki tingkat ketergantungan yang rendah telah memiliki kondisi keuangan yang baik untuk memaksimalkan pelayanan publik. Didamping itu kondisi keuangan yang baik membuat pemerintah daerah mempunyai banyak pilihan untuk meningkatkan daerah mereka dan tidak tergantung pada pemerintah pusat untuk membiayai proyek yang strategis yang dibutuhkan masyarakat. Kemampuan pemerintah daerah memaksimalkan potensi local akan dapat meningkatkan IPM secara dramatis (Dendy, 2018). Ketidakmampuan dalam kapasitas dan pengelolaan keuangan daerah akan sering menimbulkan efek negatif yaitu tingkat pelayanan yang rendah bagi masyarakat berdampak pada tidak meningkatkan IPM. Kesimpulannya adalah Semakin jelek kinerja keuangan yang dilihat dari semakin tingginya tingkat ketergantungan dan rendahnya tingkat desentralisasi fiscal di Kabupaten /kota yang 
ada di Propinsi Papua berdampak pada tidak maksimalnya Pemerintah daerah dalam memaksimalkan penyediaan sarpras pelayanan publik sehingga membuat pemda tidak mempunyai banyak pilihan strategis untuk membiayai berbagai macam kegiatan yang bermanfaat bagi peningkatan kualitas masyarakat sehingga dapat meningkatkan IPM lebih dramatis. Bila dilihat berdasarkan data IPM Papua hanya tumbuh rata rata1,32\% pertahun .bahkan ada beberapa daerah di Papua yang IPM lebih rendah dari IPM rata rata Propinsi Papua.

\section{Pengaruh Kinerja Keuangan Terhadap Indeks Pembangunan Manusia Yang Di Mediasi Oleh Belanja Modal}

Dari hasil pengujian analisis jalur diperoleh hasil bahwa secara langsung pengaruh kinerja keuangan ke belanja modal tidak berpengaruh signifikan tetapi belanja modal berpengaruh signifikan dengan arah kedua duanya negative. Uji sobel test menunjukkan bahwa $\mathrm{p}$ value $0,845>0,05$, sehingga hipotesis $\mathrm{H} 4$ tidak terdukung.. Kinerja keuangan yang dilihat dari tingkat ketergantungan yang tinggi (90\%) dan tingkat desentralisasi fiscal $(2,6 \%)$ tidak menunjukkan performance keuangan pemerintah daerah yang baik, Indikator kinerja keuangan ini mencerminkan daerah belum mempunyai kemampuan dalam mendanai kebutuhan daerah yang berasal dari potensi local secara maximal untuk membiayai pembangunan dan penyediaan infrastruktur, sarpras dalam kaitannya dengan pelayanan public seperti di bidang ekonomi, pendidikan dan kesehatan sehingga tidak terlalu berdampak sekali pada peningkatan IPM yang cukup dramatis untuk konteks Papua ratarata IPM hanya meningkat $1,3 \%$ pertahan. Kinerja keuangan yang kurang bagus menunjukkan pula bahwa pemerintah daerah di Propinsi Papua belum dapat mengali dan mengelola sumber-sumber pendapatan aslinya untuk mendanai pembangunan di daerah dan penyediaan pelayanan kepada masyarakat secara mandiri sehingga mempunyai keleluasaan di dalam menggunakan dana tersebut.Sebagian besar dana perimbangan masih banyak digunakan untuk menutupi belanja tidak langsung yang tidak mampu dipenuhi dengan PAD. Sehingga alokasi dari belanja modal dari APBD yang jumlahnya hanya 27\% yang seharusnya minima idealnya adalah $30 \%$ dari total APBD. 
Belum terbuktinya hipotesis $\mathrm{H} 4$ dalam penelitian ini dapat dijelaskan karena ketidakmampuan daerah mengangkat potensi local untuk membiayai seluruh kebutuhan daerah menyebakan daerah tidak mampu menyediakan investasi tetap yang dibutuhkan untuk layanan publik yang baik sesuai dengan kebutuhan masyarakat. Ini disebabkan karena belanja modal bukan satu-satunya yang mendongkrak IPM tetapi peran dari belanja daerah secara keseluruhan yang dikelola dengan tepat akan dapat meningkatkan kemakmuran masyarakat yang pada akhirnya akan meningkatkan IPM. Hal ini sejalan dengan Sahial (2007) alokasi belanja untuk bidang kesehatan hendaknya mampu meningkatkan angka harapan hidup yang merupakan komponen dalam penentuan kualitas pembangunan manusia. Alokasi di bidang pendidikan akan mengantarkan masyarakat dapat mengenyam pendidikan yang bermutu dan terjangkau sehingga berdampak pada peningkatan angka melek huruf sedangkan alokasi belanja infrastruktur dilakukan dengan harapan akan memberikan kontribusi bagi peningkatan pendapatan masyarakat yang selanjutnya akan meningkatkan daya beli masyarakat .

\section{SIMPULAN}

\section{Simpulan}

1. Semakin meningkatnya Dana perimbangan ( $\mathrm{DBH}, \mathrm{DAU} \mathrm{DAK})$ akan berdampak pada semakin meningkatnya kesejahteraan masyarakat yang dicerminkan dengan peningkatan IIPM.

2. Meningkatkan Dana perimbangan tidak dapat meningkatkan belanja modal yang berdampak pada meningkatnya IPM. Artinya semakin meningkatnya Dana perimbangan tidak disertai dengan peruntukaanya yang tepat tidak dapat mendongkrak peningkatan IPM ,

3. Kinerja keuangan yang dilihat dari semakin tingginya tingkat ketergantungan dan tingkat desentralisasi tidak berdampak pada peningkatan IPM

4. Meningkatkan Kinerja keuangan yang dapat dilihat dari tingkat ketergantungan dan tingkat desentralisasi tidak berpengaruh pada meningkatnya belanja modal sehingga tidak berdampak pada meningkatnya IPM. 


\section{Keterbatasan penelitian}

1. Penelitian ini hanya menggunakan komponen struktur APBD yaitu Dana perimbangan padahal belanja modal didanai juga oleh pendanaan yang lain termasuk di dalamnya juga berasal Dana Otsus yang juga membiayai sektor kesehatan, pendidikan dan ekonomi.. Penelitian ke depan diharapkan bisa memasukkan dana Otsus yang juga mengalokasikan di bidang pendidikan, kesehatan dan ekonomi dalam menjelaskan alokasi belanja modal.

2. Penelitian ini hanya menggunakan data cross section sehingga tidak dapat memprediksi IPM yang merupakan proses yang diperoleh bukan dari hanya 6 tahun. Penelitian ke depan data seharusnya menggunakan data runtun waktu ( time series) sehingga bisa menjelaskan lebih baik hubungannya dengan IPM .

\section{Saran}

1. Setiap kabupaten harus dapat membuat prioritas pemanfaatan penggunaan dana perimbangan yang tepat untuk mendanai program program/ bidang yang menjadi prioritas dalam pembangunan khususnya yang dapat membantu dalam meningkatkan IPM

2. Pemerintah Propinsi sebaiknya mengawasi peruntukan dari Dana perimbangan dengan membuat acuan skala prioritas program yang harus dikembangkan di daerah/kabupaten masing-masing sesuai dengan kondisi dan peruntukannya berdasarkan aturan yang berlaku. Sesuai dengan aturan yang berlaku

3. Untuk memberikan dampak yang positif terhadap peningkatan IPM maka sebaiknya Dana Perimbangan yang diberikan di setiap Kabupaten harus digunakan untuk belanja modal khususnya pada pengadaan investasi dengan skala prioritas pada peningkatan bidang pendidikan, bidang kesehatan dan bidang ekonomi.

4. Untuk mengurangi Tingkat ketergantungan dan Tingkat desentralisasi dan maka dibutuhkan upaya penggalian potensi pajak dan retribusi serta menguatkan BUNDES yang ada di setiap kabupaten /Kota sebagai sumber alternative pembiayaan yang kuat di setiap kabupaten /Kota. 


\section{DAFTAR PUSTAKA}

Amalia, F. R., \& Purbadharmaja, I. B. P. (2014). Pengaruh Kemandirian Keuangan Daerah Dan Keserasian Alokasi Belanja Terhadap Indeks Pembangunan Manusia. E-Jurnal Ekonomi Pembangunan Universitas Udayana, 3(6).

Anggraini, T. (2015). Pengaruh Rasio Keuangan Pemerintah Daerah Terhadap Indeks Pembangunan Manusia Pemerintah Provinsi di Indonesia. UNS (Sebelas Maret University).

Arsyad, L. (1999). Pengantar Perencanaan dan Pembangunan Ekonomi Daerah. Yogyakarta: BPFE.

Aziz, A., \& Wulandari, R. (2014). Analisis Pengaruh Equalization Grant, Sumber Kemandirian Fiskal, Sumber Pembiayaan Defisit Dan Faktor Penyerap Fasilitas Publik Terhadap Belanja Modal Daerah. Accounting Analysis Journal, 1, 1-20.

Batafor, G. G. (2011). Evaluasi Kinerja Keuangan dan Tingkat Kesejahteraan Masyarakat Kabupaten Lembata-Provinsi NTT. Program PascaSarjana: Universitas Udayana.

Bisma, I., \& Susanto, H. (2010). Evaluasi Kinerja Keuangan Daerah Pemerintah Provinsi Nusa Tenggara Barat Tahun Anggaran 2003-2007. Ganec Swara, 4(3), 75-86.

Budiartha, I. K., Badera, I. D. N., \& Tonu, D. (2015). Pengaruh Pertumbuhan Ekonomi Daerah Pada Daya Saing dengan Keserasian Belanja Daerah, Kemandirian Keuangan Daerah Sebagai Variabel Pemoderasi. E-Jurnal Ekonomi Dan Bisnis Universitas Udayana, 4, 44735.

Christy, F. A., \& Adi, P. H. (2009). Hubungan Antara DAU, Belanja Modal dan Kualitas Pembangunan Manusia. Paper The 3rd National Conference UKWMS, Surabaya.

Darwanto, \& Yulia, Y. (2007). Pengaruh Pertumbuhan Ekonomi, Pendapatan Asli Daerah, dan Dana Alokasi Umum Terhadap Pengalokasian Anggaran Belanja Modal. Simposium Nasional Akuntansi $X$.

Farel, R. (2015). Faktor-Faktor yang Mempengaruhi Belanja Modal di Kabupaten Bogor. Signifikan: Jurnal IImu Ekonomi, 4(2).

Halim, A. (2008). Akuntansi Keuangan Daerah (Edisi Keti). Jakarta: Salemba Empat.

Harianto, D., \& Adi, P. H. (2007). Hubungan Antara Dana Alokasi Umum, Belanja Modal, Pendapatan Asli Daerah Dan Pendapatan Per Kapita. Simposium Nasional Akuntansi $X, 26-28$.

Hendarmin. (2012). Pengaruh Belanja Modal Pemerintah Daerah dan Investasi Swasta terhadap Pertumbuhan Ekonomi, Kesempatan Kerja dan Kesejahteraan Masyarakat di Kabupaten/Kota Provinsi Kalimantan Barat. Jurnal EKSO, Fakultas Ekonomi Jurusan IImu Ekonomi UNTAN, 8(3), 144-155.

Ibnu, S. (1986). Pokok-Pokok Kebijaksanaan, Perencanaan, Pemrograman, Dan Penganggaran Pembangunan Tingkat Nasional Dan Regional. Jakarta: CV Rajawali.

Kuncoro, M. (2004). Otonomi dan Pembangunan Daerah. Jakarta: Erlangga.

Kusnandar, \& Siswantoro, D. (2012). Pengaruh DAU, PAD, SILPA, dan Luas Wilayah Terhadap Belanja Modal. Simposium Nasional Akuntanasi XV, Banjarmasin.

Lanjouw, P., Pradhan, M., Saadah, F., Sayed, H., \& Sparrow, R. (2001). Poverty, Education, 
and Health in Indonesia: Who Benefits From Public Spending? The World Bank.

Mahmudi. (2010). Manajemen Keuangan Daerah. Jakarta: Penerbit Erlangga.

Mardiasmo. (2004). Otonomi dan Manajemen Keuangan Daerah. Yogyakarta: ANDI.

Mardiasmo. (2009). Akuntansi Sektor Publik (Edisi Keem). Yogyakarta: ANDI.

Martini, K., \& Dwirandra, A. (2015). Pengaruh Kinerja Keuangan Daerah Pada Alokasi Belanja Modal Kabupaten Dan Kota Di Provinsi Bali. E-Jurnal Akuntansi, 426-443.

Mirza, D. S. (2012). Pengaruh Kemiskinan, Pertumbuhan Ekonomi, dan Belanja Modal Terhadap Indeks Pembangunan Manusia di Jawa Tengah Tahun 2006-2009. Economics Development Analysis Journal, 1(2).

Pangkey, A. H. R., Saerang, I. S., \& Tulung, J. E. (2017). Analisis Kinerja Keuangan Pemerintah Dearah Kabupaten Minahasa Selatan Tahun Anggaran 2011-2015. Jurnal EMBA, 5(2), 2848-2858.

PP Nomor 58 Tahun 2005. Tentang Pengelolaan Keuangan Daerah.

Praza, E. I. (2016). Analisis Pengaruh Kinerja Keuangan terhadap Alokasi Belanja Modal di Provinsi Jambi. Jurnal Perspektif Pembiayaan Dan Pembangunan Daerah, 4(1), 25-36.

Sari, I. A. C. Y., \& Supadmi, N. L. (2016). Pengaruh Pendapatan Asli Daerah Dan Belanja Modal Pada Peningkatan Indeks Pembangunan Manusia. E-Jurnal Akuntansi, 15(3), 2409-2438.

Sartika, N., Kirmizi, K., \& Indrawati, N. (2017). Analisis Faktor-faktor dalam Struktur APBD dan Kinerja Keuangan Daerah yang Mempengaruhi Belanja Modal pada Kabupaten/Kota di Provinsi Riau. Sorot, 12(2), 121-135.

Sholikhah, I., \& Wahyudin, A. (2014). Analisis Belanja Modal Pada Pemerintah Kabupaten/Kota di Jawa. Accounting Analysis Journal, 3(4), 553-562.

Sularso, H., \& Restianto, Y. E. (2012). Pengaruh Kinerja Keuangan Terhadap Alokasi Belanja Modal dan Pertumbuhan Ekonomi Kabupaten/Kota di Jawa Tengah. Media Riset Akuntansi, 1(2), 109-124.

Suryaningsih, N. N., Utama, M. S., \& Yasa, I. N. M. (2015). Dampak Kinerja Keuangan Daerah Terhadap Kesejahteraan Masyarakat Kabupaten/Kota di Provinsi Bali. E-Jurnal Ekonomi Dan Bisnis Universitas Udayana, 40(8), 537-554.

Susanti, S., \& Fahlevi, H. (2016). Pengaruh Pendapatan Asli Daerah, Dana Alokasi Umum, dan Dana Bagi Hasil terhadap Belanja Modal (Studi pada Kabupaten/Kota di Wilayah Aceh). Jurnal Ilmiah Mahasiswa Ekonomi Akuntansi, 1(1), 183-191.

Susantih, H., \& Saftiana, Y. (2009). Perbandingan Indikator Kinerja Keuangan Pemerintah Provinsi Se-Sumatra Bagian Selatan. Simposium Nasional Akuntansi, 12.

Swandewi, A. (2014). Pengaruh Dana Perimbangan dan Kemandirian Keuangan Daerah Terhadap Keserasian Anggaran dan Kesejahteraan Masyarakat pada Kabupaten/Kota di Provinsi Bali. J Ekon Bis, 3(7), 356-376.

Yanto, E., Ridwan, \& Fattah, V. (2018). Pengaruh Pendapatan Asli Daerah (PAD) dan Belanja Modal Terhadap Indeks Pembangunan Manusia (IPM) (Survei Pada Kabupaten/Kota di Sulawesi Tengah). E Jurnal Katalogis, 6(2), 125-135.

Zebua, W. F. (2014). Pengaruh Alokasi Belanja Modal, Belanja Barang Dan Jasa, Belanja 
Hibah Dan Belanja Bantuan Sosial Terhadap Kualitas Pembangunan Manusia (Studi Pada Kabupaten Dan Kota Di Wilayah Provinsi Jawa Barat Tahun 2011-2013). Universitas Brawijaya. 